wszystkim cicha i dogłębna, tworzyła w duszach wartości żywe i nieprzemijające.

Nic dziwnego, że karty przez Niego pisane w duszach ludzkich trwają i wołają o Jego Pamięć ${ }^{1}$ ).

Ks. Marian Rechowicz.

\title{
LITURGIA A DUSZPASTERSTWO
}

W pamięci wiernych zapewnił sobie Pius $\mathrm{X}$ trwałe miejsce: żyje w niej jako ten święty, dobry papież, co otworzył dla wszystkich skarby eucharystycznego życia przez swe dekrety o częstej i codziennej Komunii św. i o dopuszczeniu dzieci we wczesnym wieku do Stołu Pańskiego. Papieżem Eucharystii nazwali go już współeześni, a tym samym mianem darzy. go wdzięczna potomność.

Natomiast może nie tak powszechnie spotkał się ze zrozumieniem charakter życia eucharystycznego, jak go chciał widzieć Pius X, może mniejszą zwrócono uwagę na ramy, w jakich wedle jego pragnienia życie eucharystyczne miało się rozwinąć, na liturgię. Papież Eucharystii z pewnością, ale może jeszcze pełniej określa stanowisko i znaczenie wielkiego papieża miano: Papiéz liturgii.

Zaraz w początkach panowania swego w r. 1903 w Motu Proprio o Muzyce Kościelnej $\mathrm{z}$ dnia 22 Tistopada akcentŕje znaczenie liturgii jako środka do realizacji wielkiego rzuconego przez się hasła „Instaurare omnia in Christo". „Ażeby według gorącego życzenia mego, prawdziwy duch chrześcijański ma nowo pod każdym względem zakwitnął i zachował się u wszystkich wiernych, głównie starać się trzeba o świętość i powagę świątyni, w której wierni na to właśnie się zbierają, by ducha tego zaczerpnąć z tego pierwszego i koniecznie potrzebnego źródła, jakim jest czynne uczestnictwo w najświętszych tajemnicach, tudzież w publicznej i uroczystej modlitwie Kościoła. Na próżno oczekiwać będziemy błogosławieństwa z nieba, jeżeli nasza służba Boża, zamiast wznosić się w górę wonnością wdzięczności, weliska Panu bicz z powrózków, którymi Boski Zbawiciel wypędził ongi z świątyni niegodnych przekupniów".

1) Ku uczczeniu pamięci Ks. Csesznaka podajemy przedruk jego doskonałego

referatu p. t.: „Wyzyskanie liturgii dla celów duszpasterstwa", który się ukazał w cyklu wykładów z Kursu Duszpasterskiego we Lwowie r. 1929. 
Słowa papieża w wyrazistości swej nie pozostawają nic do życzenia. Dalszym dowodem, jak mu sprawa liturgii leżała na sercu, to reforma brewiarza. Ograniczenie Proprium Sanctorum, zniesienie oficjów wotywnych, rozłożenie psałterza na poszczególne dnie tak, aby w tygodniu cały był odmówiony, były to rzeczy nie tylko zewnętrzne, ale głęboko wnikające $w$ istotę samą życia religijnego. Było to świadome i celowe podkreślenie cultus latríae, który stanowi zasadniczą cechę modlitwy liturgicznej. Czy ogół wczuwał się w intenecję papieża, czy rozumiał w pełni doniosłość reform? Może i okoliczności, wśród których one się odbywały i epoka sama walki o podstawy katolicyzmu i religii $w$ ogóle (walka $\mathrm{z}$ imodernizmem), utrudniały pełne zrozumienie ich wagi i znaczenia. Zbył świeże były jeszcze słowa Leona XIII „o wyjściu z zakrystiil“ skierowane do kleru francuskliego, by w reformach liturgicznych Piusa $\mathrm{X}$ nie widzieć raczej kwest:ii karności kościelnej, by może nawet nie dziwlić się, że w tym strasznym ówczesnym zmaganiu się różnych prądów duchowych papież zajmuje się takimi drobiazgami.

Nie da się również zaprzeczyć, że linia reformy liturgicznej Papieża Eucharystii uległa po jego śmierci pewnemu wygięciu. Proprium Sanctorum uległo znowu powiększeniu, w oktawy najstarszych świąt (Epiphania) i w Proprium de tempore wprowadzono officia wotywne (Festum S. Familiae i SS. Cordis Jesu). Nie musi to jednak kюniecznie oznaczać ogólnej rezygnacji z liturgii i jej stylu w nabożeństwie publicznym Kościoła, ani też przekreślenia świadomego reform Pliusa X. Jest to raczej praktykowane nieraz już ustępstwo na rzecz nabożeństwa ludowego $\mathrm{w}$ ramach liturgii. Bo i z tego trzeba sobie zdać wyraźnie sprawę, że w katolicyzmie istnieją dwa równolegle biegnące prądy religijności: pobożności liturgicznej, modlitwy Kościoła we właściwym i ścisłym tego słowa znaczeniu, i pobożności ludowej. Oba te prądy są przez Kościół, chociaż inaczej, uznawane i aprobowane. W rozmaitych epokach raz jeden to znowu drugi przeważa i wysuwa się na pierwszy plan w życiu religijnym wiernych: raz pobożność liturgiczna, to znowu pobożność ludowa.

W pierwszych wiekach Kościoła istnieje tylko jedna modllitwa i jedna religijność: liturgiczna. Składają się na nią: modlitwa godzin wzięta $\mathrm{z}$ synagogi, rozwinięta przez Kościół (odmawianie psalmów i modlitw wspólnych) i Eucharystia. Z Eucharystią jako przygotowanie do niej, jako jej uzupełnienie łączą się niby ze swym ośrodkiem inne sakramenta, a nawet sakramentalia. Nie oznacza to, by chrześcijanie nie modllili się sami poza liturgią, ale i ich prywatna modlitwa 
była natchniona liturgią i obracała się $w$ jej motywach. Takie przejęcie się motywami liturgii uderza nas $n$. p. w opisie męczeństwa św. Ignacego z Antiochii: „Frumentum Christi sum; dentibus bestiarum molar, at panis mundus inveniar", a jeszcze z początkiem wieku V słyszał św. Hieronim rolników i robotników w winnicach śpiewających przy pracy psalmy.

Jaka jest cecha zasadnicza liturgiii? - Jest ona modlitwa uwielbienia (sacrificium laudis), którą Kościół zanosi do Boga. Zgromadzeni dokoła oltarza (circumstantes) tworzą wierni wraz z głową swoją Chrystusem jedno mistyczne ciało i wraz z Chrystusem, sprawującym vi sacramenti ordinis przez biskupa czy kapłana najświętszą ofiarę, ofiarują Bogu, w Trójcy jedynemu, Deo vivo et vero, pod postaciami chleba i wina Ciało i Krew Pańską, jako Hostiam puram, sanctam, immaculatam i wraz z nią, w jednym i tym samym akcie ofiarnym, siebie samych na służbę Bożą, na śmierć i życie...

Mamy tu pewne nastawienie modlitewne, które ogółowi naszych wiennych jest obce, albo te $\dot{z}$ wprost nieznane. Oto po jednej stronie niejako jest Bóg w majestacie swym, po drugiej Chrystus jako Pośrednik i Zbawca wraz ze swym Kościołem, swą Sponsa i corpus mysticum. Jest to realizacja słów św. Pawła: ,Gdyż jeden jest Bóg, jeden też pośrednik między Bogliem a ludźmi, człowiek Chrystus Jezus, który samego siebie wydał na okup za wszystkich. Jest to świadectwo Bożej ku nam miłłości, objawlione czasu swojego, którego ja jestem postanowiony opowiadaczem i apostołem" (1 Tim. 2, 6. 7). Ta śmierć ofiarna Chrystusa, o której mówi Apostoł, staje się 'w każdej Miszy św. realnie i rzeczywiście obecną $w$ sposób sakramentalny i jest zarazem ofiarą Kościoła. Jak na krzyżu i tu Chrystus występuje w pierwszym rzędzie nie jako przedmiot kultu, ale jako arcykapłan, jalko pośrednik między ludźmi a Bogiem.

Drugim zasadniczym rysem modlitwy i ofiary liturgicznej jest jej kolektywizm; jest modlitwa wspólna całego Kościoła, a nie modlitwa jednostki, która bierze w niej udział przede wszystkim jako członek tego Corpus mysticum Christi. W modlitwie tej i ofierze bierze udział cały Kościół, w inny sposób kler, w inny wierni. Przy ołtarzu skupia się niejako nie tylko Kościół walczący ale i triumfujący (modlitwa: Communicantes). Ta wspólność i jedność Kościoła w modlitwie jest dla pierwszych chrześcijan czymś itak istotnym, że Eucharystia jest dla nich symbolem Kościoła (por. Didache: modllitwę po przeistoczeniu).

Komunia święta nie tylko kapłana, ale i wiernych, jest częścią integralną liturgii mszalnej; nulla missa sine communione fidellium. 
Jest ona ucztą ofiarną i jako taka naturalnym uzupełnieniem 'samej ofiary. Wierni w pierwszych wiekach komunikują również poza mszą świętą, biorą przecież nawet Eucharystię w tym celu do domu, ale i wtedy jeszcze jest ona dla nich częścią ofiary: corpus pro mundi vita.

Jedno musi nas uderzać. Ponad wiszelką wątpliwość stwierdzoną jest wiara od samych początków Kościoła w rzeczywistą obecność Chrystusa w Najświętszym Sakramencie, a jednak brak specjalnych oznak kultu dla Eucharystii w naszym rozumienliu, brak adoracji specjalnych, tych nam tak drogich oznak hołdu. Przechowuje się Najśw. Sakrament początkowo jako komunie dla chorych w domach kapłanów, następnie w tym samym charakterze w pastiforiach czyli w naszych zakrystiach. Wierni biorą Eucharystię do domu i sami się komunikują. Nie słyszymy nic o wiecznej lampie, nie ma śladu klękania przed Najśw. Sakramentem. Kiedy zaczęto umieszczać Eucharystię w świątyniach samych, zamykano ją początkowo w otworach w murze; a następnie zawieszano w puszce lub umieszczano na ołtarzu. Tabernaculum w naszym rozumieniu zjawia się bardzo późno, gdzieś. w wieku XVI.

Nie oznacza to bynajmniej lekceważenia tej najświętszej tajemnicy, ale specjalne nastawienie duchowe wobec Eucharystii. Jest ona w pierwszym rzędzie ofiarą i strawą duszy i dlatego jako ofiara i komunlia, jako msza pochłaniała całą uwagę wiernych aż do mniej więcej XI w. Dwa czynniki wpłynęły na zmianę-tego nastawienia duchowego i zapoczątkowały rozwój kultu jako czci obeeności Zbawiciela przybywającego pod postaciami eucharystycznymi. Z jednej strony potępienie błędów Berengariusza, który przeczył prawdziwej obecności Chrystusa w tym Sakramencie, $\mathrm{z}$ drugiej wejście narodów germańskich do Kościoła. Dla germanów pojęcie ,mysterium“, jakim jest msza święta, było czymś obcym i niezrozumiałym; przy swym wrodzonym indywidualiźmie nie potrafią się wżyć 'w ideę Kościoła jako Corpus mysticum Christi i stawiają modlitwę prywatną praktycznie ponad liturgiczną. Powoli zjawia i rozwija się modlitwa skierowana nie - jak przedtem było do Boga per Jesum Christum Dominum Nostrum - ale wprost do Osoby Zbawiciela w Eucharystii; powstają specjalne ku Jego Osobie akty zewnętrznej czci. Nie Chrystus sacerdos et victima, ale Emanuel - Bóg z nami - zajmuje w świadomości religijnej i poczuciu wiernych pierwsze miejsce: adoracja i komunia; nie jest to już complementum sacrificii i cibus animae, ale osobne uczczenie Boskiego Zbawiciela. Miast dawnej sacra actio - centemplatio i beata sessio. $\mathrm{Z}$ tym nastawieniem nowym łączy się $\mathrm{u}$ wiernych moment nieznany 
w tej formie dawnemu Kościołowi, mianowicie pragnienie widzenia świętych postaci. Kościół swego sţanowiska zasadniczego nie zmienia; akcentuje dalej obowiązek brania udziału we mszy św., ale równocześnie liczy się $\mathrm{z}$ tą ,,devotio moderna" i jako zgodną z dogmatem bierze w swą opiekę i stara się ją we właściwych utrzymać granicach. Z końcem wieku XII wchodzi do mszy św. podniesienie jako adoracja Chrystusa. W wieku XIII (1264) powstaje uroczystość Bożego Ciała, a procesja $\mathrm{z}$ odsłoniętymi dla widoku ludzi postaciami sakramentalnymi odbywa się po raz pierwszy w r. 1279. Kolejno zjawia się wystawienie Najśw. Sakramentu w monstrancji, a procesje teoforyczne stają się ulubioną formą nabożeństwa ludowego, wprowadzoną mimo sprzeciwu Kościoła coraz częściej jako środek podniesienia uroczystości religijnych, choćby nie związanych bezpośrednio i w pierwszym rzędzie $z$ uczczeniem Eucharystii, jako motyw niemal dekoracyjny. Naturalnym zupełnie objawem był wzrost kultu eucharystycznego w tej nowej formie, kiedy najpierw reformatorzy XVI wieku zgodnie zaprzeczali prawdziwej obecności Chrystusa w Eucharystii, a następnie janseniści akcentując jednostronnie mysterium tremendum, odstraszali od niej wiernych (Dieu inaccessible), ale Kościół czuwał istale, ażeby i zewnętrznie odróżnić adorację od mszy św. i stąd stała ostrożność i dążność do ograniczania wystawienia Najśw. Sakramentu podezas mszy św. Klemens XI wydaje w r. 1731 rozporządzenie, dozwalające tylko na odprawienie sumy podezas 40-godzinnego nabożeństwa przy ołtarzu wystawienia.

Niemniej charakterystyczne zabarwienie przybrała w świadomości religijnej szerokiej masy wiernych Komunia św. W liturgii była i jest ona ucztą ofiarną, integralnym uzupełnieniem samej ofiary i cibus spiritualis hominis viatoris, zadatkiem szczęśliwej nieśmiertelności, annuntiatio mortis Domini donec veniat. Marana-tha ,niech przyjdzie Pan i niech przeminie świat" - rozlegało się w czasie pierwszych mszy św. Komunia była vinculum unitatis pomiędzy wiernymi. Przygotowania szczególniejszego poza braniem udziału we mszy św. chrześcijanie do komunii św. nie znali; również tylko modlitwy mszału były dziękczynieniem po przyjęciu Eucharystii. Owocem jej było ,,umiłowanie Chrystusa i uczczenie Go w bliźnich“. „Vidisti fratrem tuum, vidisti Dominum tuum..." Zwolna następuje w praktyce wiernych odłąozenie komunii św. od mszy św. i uniezależnienie się jej jako specjalnego nabożeństwa. Chrystus w pierwszym rzędzie nie jest już cibus, ale hospes animae, a jak zauważył O. Vilmart O. S. B., z tym nastawieniem zrodziła się obawa, żeby ta najśw. tajemnica ludziom nie 
spowszedniała; bo chleb nie powszednieje, chociaż codzienne spoży wamy, ale latwo natomiast spowszednié mogá odwiedziny. Za tym poszło $\mathrm{z}$ poczucia szacunku i czci coraz częstsze wstrzymywanie się od komunii św., stawianie coraz większych warunków przygotowania i dziękezynienia. Do krańcowości doprowadzili janseniści, stawiając tak wysokie żądania w tym kierunku, że komunia dla ogółu wiernych stała się torturą, której niechętnie się poddawali.

Jeżeli dodamy w w. XVI atak Lutra na mszę św. jako na bałwochwalstwo, urągające zbawczej śmierci Chrystusa i stąd zbyteczne i szkodliwe dla duszy, jego wprowadzenie komunii jako samoistnej formy kultu, jeżeli dowiadujemy się, że zapędy reformatorskie oddzia ływały i na katolików ówczesnych, to zrozumiemy niechęć, z jaką traktowano przystępowanie do komunii św. w czasie miszy i tego rodzaju pochodzące niestety od katolików ówczesnych powtiedzentie z pewnością nieliczne, ale mimo wszystko potworne, że ,,raczej umrzeć, raczej w'szystko utracić, niż komunikować w czasie mszy św.".

Zwyczaj przyjmowania komunii św. poza mszą św. pociągnął za sobą izolację wiernych od modlącego i ofiarującego Kościoła. Obecność ludzi przeszkadzała; chciało się być ,sam na sam“ z Chrystusem, zaczęto tęsknić za tym ,Minnekosen“. Akcentowano duszę poszczególną jako ,sponsa Christi“" i przeciwstawiano ją ofiejalnemu Kościołowi, który jest w pierwszym rzędzie ,sponsa Christi“. Nawet gdy słuchano mszy św., to wolano cichą, by ją traktować jako nabożeństwo prywatne, nie mącące własnej pobożności. Modlitwa wiernych w czasie takiej mszy 'św. nie miała z nią łączności. Słuchano mszy, nie brano w niej udziału. Nie Kościół, lecz kaplica są ulubionym miejscem skupienia, nie parafia, ale bractwo ze swym nabożeństwem prywatnym. Objawy te, jakkolwiek mogą nám się dziwnymi wydawać, nie są i dzisiaj rzadkością i nieraz w ostrej występują formie. I w dzisiejszej położności nierzadko w ocenie wiernych nad opus operantis przeważa opus operatum; rozmyślanie wyda się nie jednej duszy czymś większym i bardziej zasługującym wobec Boga, niż wzięcie udziału we mszy świętej, przygotowanie i dziękczynienie czymś ważniejszym od samej komunii. Unikanie nabożeństw liturgicznych, np. sumy, nieszporów, jest cechą naszej inteligencji. Ileż to pobożnych dusz praktykuje chętnie komunię św. przed mszą św., ażeby w czasie mszy odprawić dziękczy nienie?

Byłoby jednak błędem upatrywanie w tym nowym ruchu eucharystycznym tylko ujemnych stron. Zasadniczo byl to ruch dodatni i jako uzupełnienie pożądany. Przyniósł ze sobą osobisty pęd dusz do 
Zbawiciela, wywołał nowe napięcia religijnego uczucia. Nie wolno jednak zapominać, że Kościół oficjalnie swego stanюwiska dawṇego nie zmienił i że modlitwą Kościoła jako mistycznego ciała Chrystusa jest tylko liturgia.

Walka z reformacją XVI w., która uderzyła nie tylko na dogmat i moralność katolicką, ale zaatakowała konsekwentnie również istotę liturgii Kościoła, nie sprzyjała odrodzeniu życia liturgicznego wiernych. Obrona katolicyzmu skupiła się w pierwszym rzędzie na prawdach wiary i obyczajów. Nie zapomniano o liturgii; książeczka rekolekcyjna św. Ignacego (Regulae ad sentiendum cum Ecclesia, Reg. tertia) poleca wyraźnie: laudare missae auditionem frequentem, item cantus, psalmos et longas orationes in Templo et extra illud; item horas ordinatas tempore destinato ad omne officium divinum et ad omnem orationem et omnes horas canonicas, ale $\mathrm{w}$ praktyce uprawiano i szerzono nabożeństwo prywałne, odłączone od liturgii, zwalczając w ten sposób indywidualizmem indywidualizm protestancki. Po tej samej linii poszedł wiek 17-ty i 18-ty, jako epoka oświeconego rozumu wprost wrogie wobec liturgii zajmował stanowisko. Chciał ją po swojemu ,reformowaćc", to jest, o iile możności, zracjonalizować i pozbawić pierwiastka nadprzyrodzonego. Józefinizm widział w niej czynnik do nauczania wiernych, poza tym pragnął ją jak najbardziej ograniczyć i uprościć. Były to głosy nie tylko świeckich ludzi niestety, ale i wielu z kleru ówczesnego myślało podobnie. Wymowną ich ilustrację stanowi fakt opowiedziany przez Albana Stoltza. Przy egzaminie kandydatów do święceń kapłańskich jeden z profesorów zalecał zaniechanie odmawiania brewiarza, a w zamian raczej przeczytanie rozdziału $z$ Naśladowania...

$\mathrm{Na}$ fakultetach teologicznych do niedawna liturgii jako osobnego przedmiotu nie uczono; wynosiliśmy z seminariów duchownych prawie wyłącznie tylko rubryki, a nie liturgię, chociaż jako kapłani mieliśmy być ex professo liturgami. Renesans życia liturgicznego rozpoczął się w drugiej połowie XIX wieku, a łączy się z nazwiskami we Francji Opata Guérangera, w Niemczech kanonika Moufanga. Dekrety i cała działalność wielkiego papieża Piusa X, jak już wspomniałem, dała potężny impuls dzisiejszemu ruchowi liturgicznemu, którego ogniskami stały sie klasztory benedyktyńskle, a który już tu w Polsce zapuścił korzenie zwłaszcza wśród młodzieży akademickiej.

Jak przedstawia się stos un e k lit u r g i i d o d u s z p asterstwa? Na to pytanie szukamy odpowiedzi. Być może, że nie zawsze ten związek wystąpi jasno, że w praktyce zdawać się będzie 
nieraz, że liturgia raczej utrudnia, niż ułatwia prace nad duszami, że nieraz wobec strasznego zaniedbanlia religijnego $\mathrm{w}$ duszach przyjda duszpasterzowi na myśl słowa św. Pawła: „Non misit me Christus baptizare, sed evangelizare" (1 Kor. 1, 17).

Liturgia powstała na Kalwarii, gdy Chrystus spełniał Swą ofiarę, aby przez śmieté dać duszę Swą na okup za wielu. Wyszła ona również $z$ wieczernika, gdzie Chrystus tę samą ofiarę złożył w sposób bezkrwawy, gdzie równiez w sposób sakramentalny wydał swe Ciało i Krew na zbawienie świata. Przez śmierć Swą stał się Chrystus' „Princeps pastorum“, „Episcopus animarum nostrarum“ i posiadł na własność dusze nasze. On jest jedynym właściwym pasterzem naszym i wszelkie duszpasterstwo w Jego ,oddaniu duszy za owce Swe“ bierze początek. Z krzyża wytrysnął zdrój łask i tèn sam zdrój tryska w każdej mszy św. i zrasza świat cały. Mówimy na razie o Eucharystii, ale to samo da się w pewien sposób twierdzić o w'szystkich sakramentach; bo we wszystkich Passio Christi est causa sanctificationis nostrae. Tak przy odprawianiu mszy św. i sprawowaniu sakramentów stajemy u źródła duszpalsterstwa naszego i otrzymujemy potwierdzenie duszpasterzowania naszego, jakeśmy wzięli również przez liturgię, t. j. przez sakrament kapłaństwa.

Ale liturgia jest zarazem celem naszego duszpasterstwa. Zadaniem naszym doprowadzić wiernych, by uwielbiali Boga. Celem pierwszym liturgii jest również uwielbienie Boga, które składa $\mathrm{Mu}$ w niej Chrystus. Nasze uwielbienie będzie tym doskonalsze, im bardziej połączymy nasze uwiellbienie z chwałą, którą Mu daje Syn Boży w liturgii. I tak liturgia staje się celem naszego duszpasterstwa, a im więcej dusz doprowadzimy do zrozumienia liturgii i należytego godnego w niej uczesinniczenia, tym lepiej spełnimy jako du'szpasterze zadanie nasze.

Na koniec jest liturgia źródłem wszelkiego uświęcenia naszego; jako duszpasterze mamy doprowadzić do dusz ludzkich łaskę Bożą, a tę właśnie znajdujemy w liturgii. $Z$ niej począwszy od sakramentu chrztu, czerpią ją dusze ludzkie i przez liturgię, t. j. udział we mszy św. i sakramentach, podtrzymują i rozwijają ją aż do pełności Chrystusowej.

Chciałbym uchylić wszelkie możliwe nieporozumienie. Podkreślenie liturgii jako źródła i celu, jako środka wszelkiego duszpasterstwa, nie oznacza bynajmniej, że duszpasterz ma się tylko do odprawiania liturgii ograniczyć, że ma się ,,zamknąć w zakrystii̛“. Byłby to bardzo powienzchowny wniosek. Właśnie postawienlie liturgii i uczestniczenia w niej godnego, pełnego zrozumienia i przejęcia się wiernych, jako celu duszpasterstwa, pociągnie za sobą konieczność użyoia wszelkich możli- 
wych srodków i wymagać będzie wytrwałej, wyczerpującej wprost pracy społecznej. Ale duszpasterstwo nasze otrzyma konkretny cel i ośrodek działania, a zarazem znajdzie w liturgili myśli i motywy zapładniające naszą działalność zewnętrzną i silną ostoję w pracy.

Mówi się wiele o religijności czy braku religijności w naszych czasach. O sąd sprawiedliwy w tym względzie trudno. Jedno zjawisko uderza nas dość często: człowiek dzisiejszy odezuwa potrzebę Boga, chce się zbliżyć do Chrystusa, ale równocześnie zatrzymuje się przed Kościołem. Nieraz usłyszeć można, że Kościół przesłania mu Boga i Chrystusa. Pomijam kwestię. czy i ile winy należałoby złożyć na element ludzki w Kościele, ile winy znajdzie się w samych tych duszach. Na jedno zwrócić można by jednak uwage. czy dzisiejszy człowiek nie patrzy zbyt czesto na Kośció jako instytucję tylko czysto prawną lub té cathedram veritatis $w$ naszym, a jarzmo duchowe w jego znaezeniu, a idea mistycznego ciała Chrystusa, idea Kościoła jako Chrystusa, żyącego w dalszym ciągu w ludzkości, jest mu może i dlatego, że rzadko lub też nigdy o tym nie mówiono, zupełnie obca. A przecié: „Quo iter nobis ad Christum pateat, (Pius X, 4 października 1903: E supremi apostolatus cathedra) ante oculos est: per Ecclesiam videlicet. Quamobrem iure Chrystostomus: Spes tua Ecclesia, salus tua Ecclesia, refugium tuum Ecclesia“. Tego wewnętrznego przeżycia, gdzie spotyka się z Chrystusem jako dawcą , "żywota wiecznego" dzisiejszy czlowick nie znajdzie poza liłurgią, ani też nie poczuje się członkiem corporis Christi, a jego religijnośé, odłączona od wiecznych źródeł liturgii, może go łatwo zawieść na manowce. Jest to objaw laicyzmu, określanego jako szczególne niebezpieczeństwo, a polegającego na zupełnym zapoznaniu nadprzyrodzonej roli Kościoła, tak, że gdy zbudzi się w nim polrzeba nadprzyrodzoności, to człowiek tego rodzaju, gotów nawet zabłądzić na bezdroża teozofii, antropozofii czy innego rodzaju gnozy wspólczesnej. a nie zwréci się do źródła prawdziwej mistyki, do Kościoła. Tymczasem pedzi życie swe bez żadnego związku z Kościolem, chociaż nawet uczęszcza na msze. której ,słucha“ i od czasu do czasu przystępuje do komunii św., ale to wszystko jest jego rzeczą ,prywatną". Dla typów takich wprowadzenie w życie liturgiczne, przepojone wspólną modlitwą Kościoła, owiane nadprzyrodzonym tchnieniem sakramentów i sakramentaliów, staje się najlepszą drogą do ,sentire cum Ecclesia“ do „vivere cum Ecclesia“ całą swą istotą.

Na koniec jeszcze jedno konkretne pytanie. Jako duszpasterzom samoistnym, proboszczom, powierza nam Kościół pewną społeczność, ściśle określoną gminę kościelną. parafię. Ideałem naszym będzie stwo- 
rzenie $z$ tych dusz licznych cor unum et anima una. Co ma tych ludzi ze sobą zespolić jako społeczność religijną? Chyba nie salma tylko kancelaria parafialna, ani też wyłącznie działalność nasza społecznoekonomiczna. Dawny Kościól znał i przekazał nam tajemnice tej podziwianej przez pogan wzajemnej miłości i łączności pomiędzy chrześcijanami. Quotidie perdurantes unanimiter in templo et frangentes circa domos panem (Đzieje 2, 46). Wspólna modlitwa liturgiczna, odmawianie psalmów i fractio panis, msza św., inaczej mówiąc: liturgia.

Pozostaje jeszcze omówienie środków, jakich użyć należy, by wiernych wprowadzić w życie liturgiczne. Wielką rolę będzie miało do spełnienia kaznodziejstwo, potrzebne są bardzo kazania dogmatycznie poprawne o mszy św. i wyjaśnienie liturgii mszalnej. Jest to zresztą wyraźne życzenie Kościoła. Mówi o tym sobór Trydencki sess. XIX w związku z kwestią narodowego języka mszy, którą załatwia negatywnie:

„Etsi Missa magnam contineat populi fidelis eruditionem, non tamen expedire visum est Patribus, ut vulgari passim lingua celebraretur. Quamobrem... ne oves Christi esuriant, neve parvuli panem petant et non sit, qui frangat eis: mandat Synodus pastoribus et singulis curam animarum gerentibus, ut frequenter inter Missarum celebrationem vel per se vel per alios, ex his, quae in Missa leguntur, inter cetera sanctissimi huius Sacrificii mysterium aliquo modo declarent, diebus praesertim Dominicis et festis“. W kazaniach należy przeto zwrócić uwagę wiernych, że i oni mogą brać czynny udział w Ofierze mszy św., że podczas przeistoczenia, kiedy Chrystus zstępuje na ołtarz i kiedy śmierć Jego staje się w sakramentalny sposób obecną, powinni Ojcu Niebieskiemu ofiarować od siebie. Syna Bożego, a z tą przenajdroższą Ofiarą ofiarować również siebie samych na pełnienie woli Bożej na cały tydzień, na śmierć i życie. W ten sposób spełnią rołę Najświętszej Matki, która stojąc pod Krzyżem ofiarowała od siebie Syna swego, a z Nim siebie sama za zbawienie świata. Przy tym można im zwrócić uwagę, że mogą ofiarować nie tylko siebie samych, ale i tych, którzy pójść na mszę św. nie mogli, lub nie chcieli. Przede wszystkim podkreślać trzeba, że ofiarując się w ten sposób, ofiarują się wraz z wszystkimi współobecnymi ma danej mszy św., że to ofiara nie pojedyńczych ludzi, lecz całej ich własnej parafii, całego Kościoła na kuli ziem'skiej. Takie nastawienie to wyrwanie $\mathrm{z}$ ciasnego kółka osobistych trosk i pragnień, a przez odpowiednie poddawanie intencji można wiernych zainteresować sprawami Kościoła całego. 
Nadto przypomnieć należy, by w duchu darowywali sobie wzajemnie urazy: - , , a kiedy niesiesz dar twój do oltarza..." Przy tłumaczeniu obrzędów mszy św. nie wolno zapominać, że mamy w niej r e a ln e wprawdzie, ale nie realistyczne uobecnienie i odtworzenie męki i śmierci Pańskiej, i że ono następuje podczas przeistoczenia. Dlatego nie można dopatrywać się szczegółów Męki Pańskiej już we mszy katechumenów, ani też posługiwać się niewłaściwymi tłumaczeniami poszczególnych ceremonii, jakie błąkają się jeszcze zawsze po naszych książeczkach do nabożeństwa, np. „Kapłan całuje ołtarz — Judasz (sic) całuje Pana Jezusa“, — ,Kapłan umywa ręce“ — Piłat je umywa, albo też „Kapłan spożywa komunię św. — Pan Jezus zstępuje do grobu“ itp.

Nader wdzięcznym tematem kazania może być omówienie i wytłumaczenie przynajmniej w ważniejsze uroczystości i święta formularza danej Miszy św. Wiernym odtworzy się znaczenie roku kościelnego, jego poszczezćnyeh czéci i jego związku z liturgią mszalną: życie i śmieré Chrystusa, które stają się obecne podczas każdej Mszy św., rozkłada Kościół na poszczególne święta, aby wierni mogli w nich na daną tajemnice zwrócić uwagę. W łączności z wykładem Mszy św. omówić kaznodzieja może w cyklu kazań i rolę komunii św. jako komunii ofiarnej, przyjętej w czasie mszy św., pieczęci postanowień i ofiary naszej, a zarazem mocy i siły na życie codzienne, którą nam Chrystus obecny w duszy naszej daje. „Jako mnie posłał żyjacy Ojciec, a ja żyje przez Ojca, tak kto pożywa mnie, żyć będzie przeze mnie". Z tym łączy się zachęta do komunii częstej i codziennej i podanie warunków ku temu potrzebnych, a zarazem wytłumaczenia przygotowania do dziękczyniénia po Komunii św. Tu pora, by zwrócić uwage na przyjmowanie Komunii podczas Mszy św., że dalej najlepszym przygotowaniem jest podany wyżej czynny udział w ofierze najśw., że dziękczynienie należałoby właściwie odprawić nie za samą Komunię, ale za całą Mszę świętą. Oczywiście trzeba ułatwić wiennym przystępowanie do Komunii świętej podczs imszy i w tym celu odprawiać mszę, o ile możności przy ołtarzu, na którym znajduje się Najświętszy Sakrament.

Nader ważną rzeczą jest akcentowanie Komunii św. jako sakramentu, jednoczącego nas nie tylko $\mathrm{z}$ Chrystusem, ale $\mathrm{i}$ nas samych jako wiernych między sobą, łączność między Christi Corpus verum, a Christi corpus mysticum i płynącym stąd obowiązkiem czynnej miłości bliźniego: ,abyście się społecznie miłowali“. Taki przykład połączenia liturgii i sakramentów znajdujemy u św. Gnzegorza z Nazjanzu. Jest to przemówienie po chrzcie, bierzmowaniu i Kolmunii św. neofitów: ojeiec Kościola przypomina im, że stali się bogatymi, że nasycił ich 
Chrystus Ciałem i Krwią Swoją, że uzdrowił ich duchowe rany i wzywa, by to samo miłosierdzie okazali braciom swym, aby nakarmili głodnego, którego spotkają, przyodziali nagiego itd.

Po gruntownym wyłożeniu istoty i obrzędów mszy św. można przystąpić do zaznajomienia wiernych z mszałem polsko-łacińskim, by modlić się mogli razem z księdzem. Na dalszym planie była by msza, t. zw. dialogata, polegająca na tym, że wierni wszyscy odmawiają ministranturę głośno i wraz z celebransem pewne części, jak Gloria Credo, Sanctus, Agnus Dei a przed Komunią wiernych Domine non sum dignus. Jest to sprawa dość pracowita, bo wymaga éwiczenia w odmawianiu chóralnym.

Oprócz mszy św. tematem szczególnego pouczenia stać się musza sakramenta w ogóle. Wierni muszą przestać widzieć, jak to nieraż się dzieje, tylko zewnętrzne formy i zrozumieć, że przez nie uczestniczymy w życiu nadprzyrodzonym, wysłużonym śmiercią Chrystusa, i otrzymujemy owoce Jego błogosławionej Męki. Poza sakramentem pokuty, jako lekarstwem grzechu i chorób duszy, poświęcić należy uwage sakramentowi chrztu, jako odrodzeniu duchowemu, bierzmowania, przez które nabywamy w pełni prawa obywatelstwa, sacerdotium regale, w Kościele i Ostatniego namaszczenia, jako przygotowania bezpošredniego do chwały wiecznej. Specjalnie ważnym będzie pouczenie o sakramencie małżeństwa ze stanowiska liturgii i —o ile możności łączenia go ze Mszą św. Kazania o kapłaństwie Chrystusowym nauezą wiernych cenić powołanie kapłańskie i kler.

Pożądane by były bardzo malutkie broszurki, zawierające liturgię paszczególnych sakramentów w języku polskim i łacińskim, by wierni mogli się z nich modlić podezas udzielania np. chrztu, czy ostatniego namaszczenia, czy też przy pogrzebie.

Wreszcie jeszcze słów kilka o sakramentaliach. Lud przywiązuje do nich nieraz rozmaite zabobony, inteligencja nie ma zazwyczaj dla nich żadnego zrozumienia. W rzeczywistości działają one ex opere orantis Ecclesiae. Przez nie wciąga Kościół nierozumną naturę w sferę odkupienia, uświęca, błogosławi szarzyznę codziennego dnia, aby nie przynosiła szkody naszej łączności z Bogiem. Tak należy rozumieć poświęcenia ziół, potraw i t. p. Obowiązkiem duszpasterza będzie często w tym kierunku pouczać wiernych, a przy spelnianiu danego sacramentale może $z$ pożytkiem wyjaśnić uprzednio ceremonie, przetłumaczyć modlitwy i w ten sposób nauczyé wiernych ich używania. Sposobności dostarczy poświęcenie pól, domów itd. Osobno może podkreślić należy Benedictio infantium: dziś zwłaszcza takie błogosławień- 
stwo dzieci przy oddawaniu ich do szlooly, podjęte publicznie w kościele, było by na czasie.

Tak by przedstawiał się w najogólniejszym zarysie temat o wy, zyskaniu liturgii dla celów duszpasterskich. W praktyce będzie wymagało to od nas samych poważnego studium, aby się wżyé w modlitwę kościoła i starać się ją zrozumieć. Ksiądz, który zna dobrze mszał, powiedział biskup Dupanloup, nie będzie złym teologiem. Ale zarazem praca w tym kierunku będzie tą najbardziej kapłańską, tym duszpasterskim realizowaniem szczytnego hasła św. Benedykta: ,Nihil Operi Dei praeponatur".

S. p. Ks. Karol Csesznák.

\section{ŚWIĘTO WNIEBOWZIĘCIA NAJŚWIĘTSZEJ MARII PANNY A SPRAWA DOGMATU MARIOLOGICZNEGO}

Od czasu ogłoszenia dogmatu Niepokalanego Poczęcia Najśw. Marii Panny, a zwłaszcza od soboru watykańskiego, stała się aktualna w Kościele sprawa dogmatyzacji Wniebowzięcia, czyli uroczystej definicji, orzekającej, iż nauka o Wniebowzięciu Matki Bożej jest objawioną i stanowi przedmiot wiary. Owej dogmatyzacji zaczeto się zewsząd od Stolicy Apostolskiej coraz natarezywiej domagać. Rozwinął się w Kościele szeroko t. zw. ruch asumpcjonistyczny, mający niezmordowanych promotorów w osobach takich entuzjastów nowej definicji dogmatycznej, jak benedyktyni Vaccari i Renaudin, jezuita Salvador, księża Bartolo Longo, Crosta di Como i in. Z ogłoszonych niedawno dokumentów archiwalnych, dotyczących nowego ruchu ${ }^{1}$ ) wynika, iż w latach 1869 do 1941 nadeszły do Rzymu petycje w sprawie dogmatyzacji Wniebowzięcia od przeszło ośmiu milionów katolików z całego świata, a w tym od 113 kardynałów, 2505 arcybiskupów i biskupów: przeszło 32 tysięcy kapłanów świeckich i zakonników oraz około 51 tysięcy zakonnic.

A w związku z napływem do Stolicy Apostolskiej ze wszystkich stron świata próśb o orzeczenie dogmatyczne w sprawie Wniebowzięcia, rozwinęły się też gruntowniejsze studia naukowe w tym przedmiocie, których owocem jest niezliczona ilość rozpraw i artykułów, mnożących

1) Petitiones de Assumptione corporea B. V. Mariae in caelum definienda ad S. Sedem delatae, propositae... a Guilhelmo Hentrich et Rudolpho Gualtero de Moos. t. I-II, Città del Vaticano 1942. 